\title{
COMBUSTION CHARACTERIZATION OF COAL FINES RECOVERED FROM THE HANDLING PLANT
}

Quarterly Technical Progress Report No. 5 Report Period: October 1, 1995 to December 31, 1995

By:

Masudi, Houshang; Principal Investigator Samudrala, Surender Rao; Graduate Research Assistant Mohannad, Omeir; Graduate Research Assistant Wright, Carol; Undergraduate Research Assistant Reid, Elna; Undergraduate Research Assistant

S.N. Dwivedi; Project Consultant

January 1996

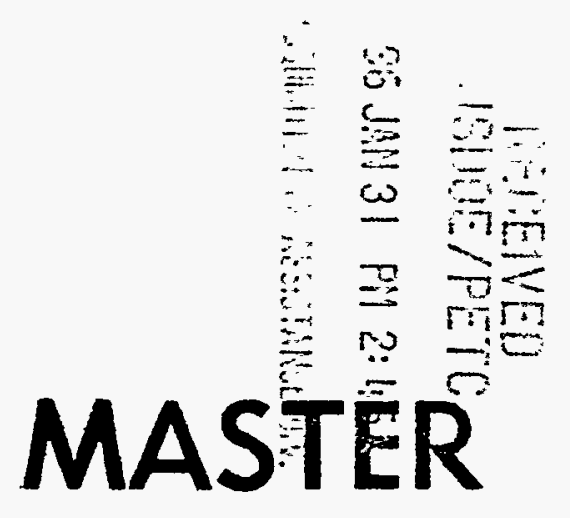

Work Performed Under Contract No. DE-FG22-94PC94122 For United States, Department of Energy Pittsburgh Energy Technology Center Pennsylvania 


\section{ABSTRACT}

The main goal of this research project is to evaluate the combustion characteristics of the slurry fuels prepared from the recovered coal fines and plant coal fines. A specific study was completed which collected data on combustion behavior, flame stability, ash behavior, emissions of $\mathrm{SO}_{2}$ and $\mathrm{NO}_{\mathrm{x}}$, and particulate in a well insulated laboratory scale furnace. In addition, the residence time and temperature history of the burning particles are similar to that of utility boiler furnace at $834,330 \mathrm{Btu} / \mathrm{hr}$ input at an average of $15 \%$ excess air. The slurry fuel was prepared at $53.5 \%$ solid to match the generic slurry properties. The coal blend was prepared using a mixture of $15 \%$ wet milled pond fines and $85 \%$ plant fines. Combustion characteristics of the slurry fuels were determined at three different firing rates: $834,330 \mathrm{Btu} / \mathrm{hr}, 669,488$ $\mathrm{Btu} / \mathrm{hr}$, and 508, $215 \mathrm{Btu} / \mathrm{hr}$. Finally, a comparison of the results will be developed for determining the advantages of coal-water slurry fuel over the plant coal blend form.

\section{OBJECTIVES}

The main objective of this project is to determine the combustion characteristics of coal-water slurry fuel prepared from the recovered coal fines and plant coal fine fractions.

The specific goals of this project are:

- Preparation of a stable coal-water slurry fuel and evaluation of its rheological properties.

- Determination of the flame stability characteristics

- Evaluation of the combustion efficiency.

- Evaluation of the fuel's fouling potential.

- Examination of emissions of $\mathrm{SO}_{2}, \mathrm{NO}_{\mathrm{x}}, \mathrm{CO}, \mathrm{CO}_{2}$, and $\mathrm{O}_{2}$

- Comparison of coal-water slurry and blended coal combustion results.

\section{INTRODUCTION}

During this period we received additional data from the Engineering Environmental Research Center (EERC) on fly-ash size distribution and fly-ash composition. The analyzed samples were taken from run number AF-CTS-713, firing at a rate of approximately $652,000 \mathrm{Btu} / \mathrm{hr}$. This additional data and previous data on the combustion tests are being analyzed to meet the project objectives and contained in appendix A. 


\section{PROJECT STATUS}

The combustion tests have been completed and all data has been received, analysis of the data is in progress.

Houshang Masudi, (Principle Investigator) and Surender Samudrala, (Graduate Research Assistant)

Have completed a paper on chemical constituents of coal-water slurry, prepared from plant coal and effluent recovered fines and its combustion disposals. This report will be presented at the Energy Week Conference in Houston, Texas on February 2, 1996.

(See Appendix B)

\section{Surender Rao Samudrala, (Graduate Research Assistant)}

Had a chance to travel to Lafayette, Louisiana to work with S.N. Dwivedi, project consultant; from December 15, 1995 until January 13, 1996. The results of their analysis are shown in the paper titled "Analysis of Gaseous Emissions Resulted from Combustion of Coal-Water Slurry". This report will be presented at the 4th Annual Historical Black College and University Conference, sponsored by the Department of Energy.

(See Appendix C)

Mohannad R. Omeir, (Graduate Research Assistant)

Studied the effect of firing rates on the combustion characteristics of coal-water slurry.

\section{Carol Wright, (Undergraduate Research Assistant)}

Has assisted the graduate assistants, and worked on several aspects of this project.

EIna L. Reid, (Undergraduate Research Assistant) has been recently added to the project and is currently conducting studies on coal as a future resource to succeed oil. Certain results of her analysis are shown in the paper titled "Contribution of Coal in the Oil-Less Future".

(See Appendix D)

\section{CONCLUSION}

The data is continually being analyzed for combustion behavior, flame stability, ash behavior, emissions of $\mathrm{SO}_{2}$ and $\mathrm{NO}_{\mathrm{x}}$, and particulates. Evaluation of experimental data used to compare the performance of coal fine-plant coal blend fuel with coal fine-water slurry fuel is still in progress. 


\section{APPENDIX A}

DISCLAIMER

This report was prepared as an account of work sponsored by an agency of the United States Government. Neither the United States Government nor any agency thereof, nor any of their employees, makes any warranty, express or implied, or assumes any legal liability or responsibility for the accuracy, completeness, or usefulness of any information, apparatus, product, or process disclosed, or represents that its use would not infringe privately owned rights. Reference herein to any specific commercial product, process, or service by trade name, trademark, manufacturer, or otherwise does not necessarily constitute or imply its endorsement, recommendation, or favoring by the United States Government or any agency thereof. The views and opinions of authors expressed herein do not necessarily state or reflect those of the United States Government or any agency thereof. 
Date: $\quad$ 07-Nov-95

Fund Number: 5457

Sample Number: 951095

Coal Laboratory Number: NMARL

Sample Description: ESP Ash EOR Run AF-CTS-713

Sample Submitter: Gunderson

Analyst: Cathy O'Keefe

\begin{tabular}{|c|c|c|c|c|c|c|}
\hline $\begin{array}{l}\text { Oxides } \\
\text { (wt. \%) }\end{array}$ & (a) & (b) & (c) & $\begin{array}{l}\text { Elemental } \\
\text { (wt.\%) }\end{array}$ & (d) & (e) \\
\hline $\mathrm{SIO} 2$ & 58.6 & 57.7 & 58.4 & $\mathrm{Si}$ & 51.1 & 51.5 \\
\hline $\mathrm{AL2O} 3$ & 19.7 & 19.4 & 19.6 & $\mathrm{Al}$ & 19.4 & 19.6 \\
\hline FE2O3 & 12.2 & 12.0 & 12.2 & $\mathrm{Fe}$ & 15.9 & 16.1 \\
\hline $\mathrm{TIO} 2$ & 1.3 & 1.3 & 1.3 & $\mathrm{Ti}$ & 1.4 & 1.5 \\
\hline P2O5 & 0.2 & 0.2 & 0.2 & $P$ & 0.1 & 0.1 \\
\hline CAO & 2.4 & 2.3 & 2.4 & $\mathrm{Ca}$ & 3.1 & 3.2 \\
\hline MGO & 2.8 & 2.7 & 2.8 & $\mathrm{Mg}$ & 3.1 & 3.2 \\
\hline $\mathrm{NA} 2 \mathrm{O}$ & 1.1 & 1.1 & 1.1 & $\mathrm{Na}$ & 1.5 & 1.5 \\
\hline $\mathrm{K} 2 \mathrm{O}$ & 2.2 & 2.1 & 2.2 & $\mathrm{~K}$ & 3.4 & 3.4 \\
\hline $\mathrm{SO} 3$ & 1.2 & 1.2 & - & $S$ & 0.9 & \\
\hline
\end{tabular}

Total $\quad 101.5$

(a) Oxide concentrations (wt.\%) on an ash basis.

(b) Oxide concentrations normalized to a closure of $100 \%$.

(c) Oxide concentrations renormalized to a SO3-free basis.

(d) Elemental concentrations (wt.\%) on an ash basis.

(e) Elemental concentrations renormalized to a S-free basis.

Comments: 
SAMFLF ID: 95-0977 L*1997 ESP ASH AF-CTS-713 -200 MESH SAMFLE

LENS TYYE: 63 MM LENS SKALL CELL/ETOHIUTRASONICS

DATE: $11-01-95$

OFERATOR: JANELLE HOFFARTH FOR J. GLRDERSON

System number 2362 Diode at 1301

Malvern Instrunents EASY Particle Sizer M.

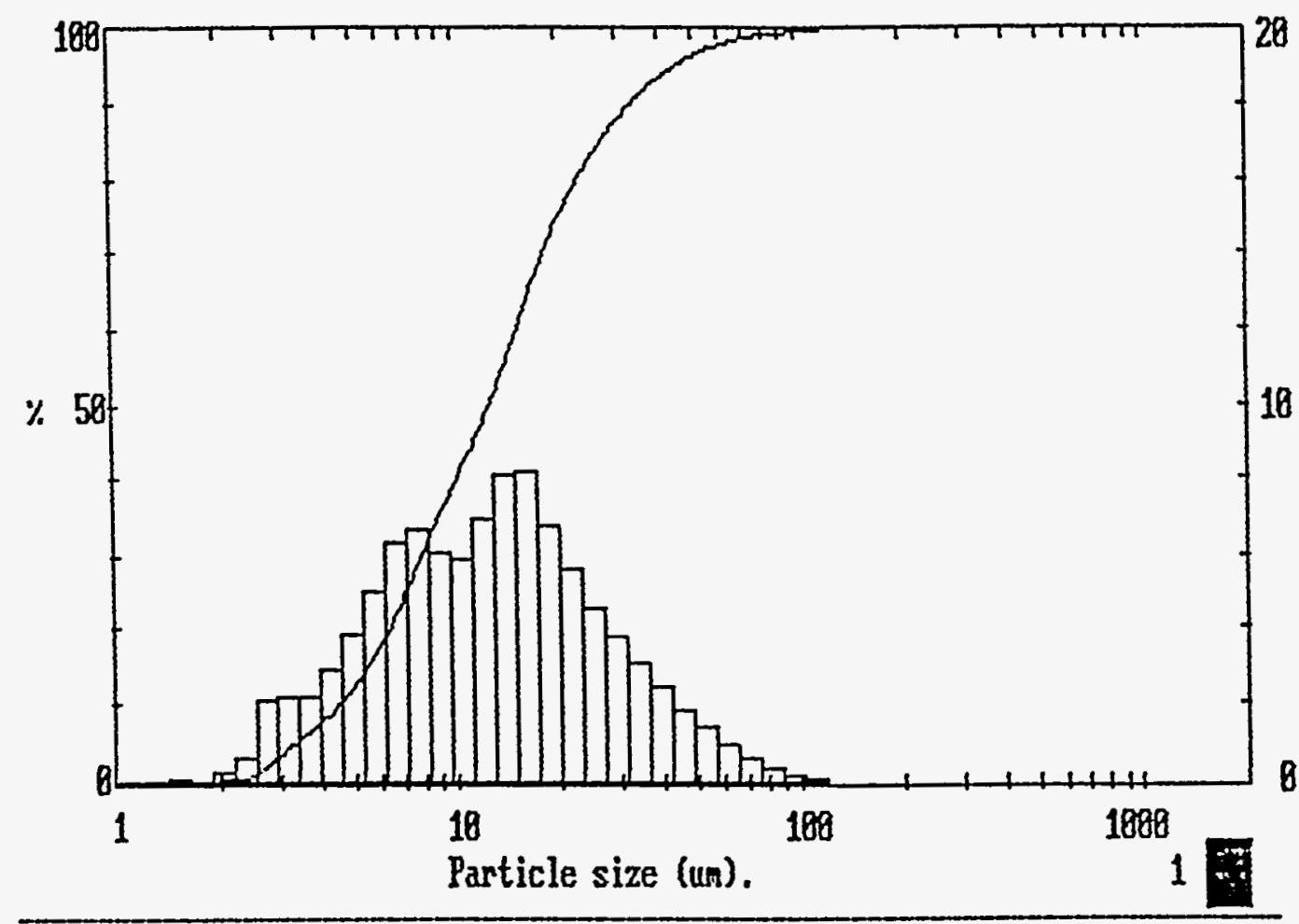

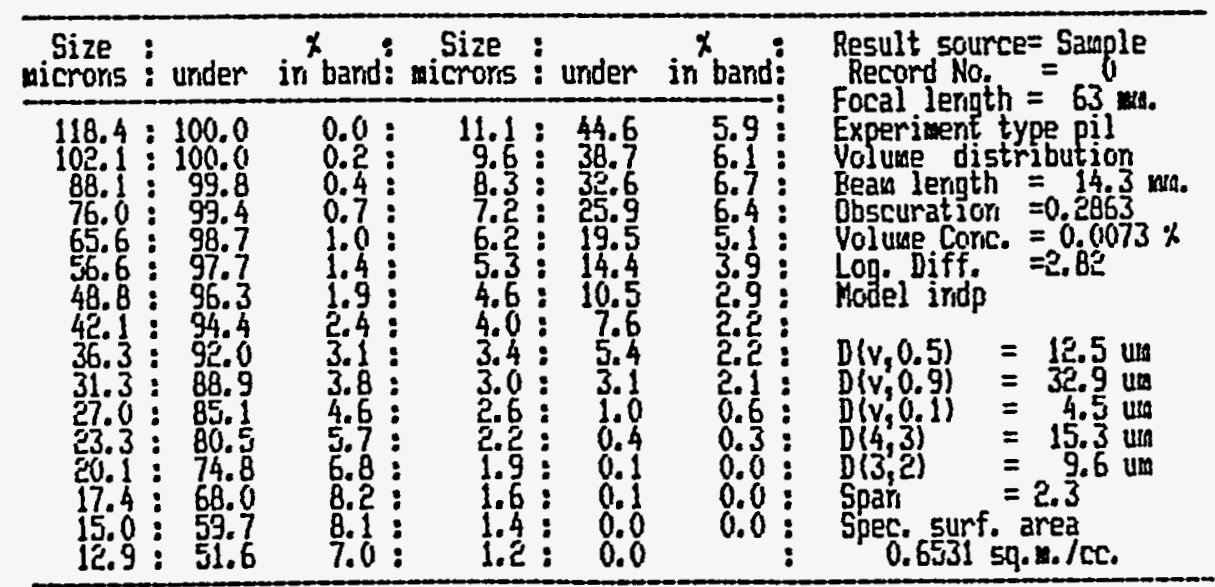


APPENDIX B

Preprint removed. At 
APPENDIX D 


\section{CONTRIBUTION OF COAL IN THE OIL-LESS FUTURE}

Coal deposits are needed as a solution to the energy dilemma. Once coal has been extracted, it can be utilized as a raw solid, processed to improve its qualities as a solid fuel, or converted into either gas or oil.

Coal is a solid, brittle, more or less distinctly stratified combustible, carbonaceous rock. A primary class of coal development is extraction from natural deposits; secondary class is preparation is the use of physical properties to benefice extracted coal and separate noncombustitibles. Tertiary class is blending, mixing of coals with different properties; and quaternary class is utilization which is actual use of coals in plant or process applications.

There are three distinct microscopic constituents, called macerals. 1) Vitrinite, plant-matter remains, 2) Exinite, waxy-resinous components, and 3) inertinite, a group of several distinct organic remains, particularly fusinite. Exploration of these groups allows a process to occur called coalification and is described as a gradual increase in carbon content of fossil organic material in the course of a natural process. From the process progressive changes appear in physical and chemical properties subsequent to burial in the sedimentary environment.

Coals contain a variety of inorganic mineral compounds. Present in mineral matter may be (1 silicates of alkalis, calcium, magnesium, iron, and titanium; 2) oxides of iron and silica; 3 ) carbonates of iron, calcium, and magnesium (which may change to oxides or heating); and 4) sulfides of iron and minor amounts of sulfates, phosphates, arsenides, and others.

Physical properties of coal are determined by $\mathrm{x}$-ray diffraction, ultraviolet and visible absorption, reflectance, refractive index, infrared absorption, electron -spin resonance, proton-spin resonance, electric conductivity, diamagnetic susceptibility, dielectric constant, sound velocity, density, porosity, strength, reflectance, caking properties, and heating value. The importance to processing is density, physical constitution, and heating value. Coal is a porous substance. There is a general correlation between density and ash content. 


\begin{tabular}{|c|c|}
\hline DENSITY & ASHCONTENT \% \\
\hline $1.3-1.4$ & $1-5$ \\
\hline $1.4-1.5$ & $5-10$ \\
\hline $1.5-1.6$ & $10-35$ \\
\hline $1.6-1.8$ & $35-60$ \\
\hline $1.8-1.9$ & $60-75$ \\
\hline $1.9>$ & $75-90$ \\
\hline
\end{tabular}

There are six physical constitutions of coal:

Color - Darkening of color from peat to subbituminous.

Luster - Low rank coals (peat, lignite) are dull higher ranks

(subbituminous and bituminous) have a progressively brighter luster.

Constituent - Essentially unaltered plant debris can be recognized in peat and lignite.

Porosity - $89 \%$ Carbon; low rank have a wide variation in porosity, high rank from minimum, the increase is small and varies over a narrow range.

Strength - Hardness

Reflectance - Incident light reflected from a polished coal surface.

Two main classes of coal analyses are 1) Ultimate analysis, determines the - elemental composition of the coal (carbon, hydrogen, sulfur, nitrogen, and ash content; oxygen is estimated by difference). 2) Proximate analysis, determines the presence of certain coal compounds (moisture, volatile matter, and ash; fixed carbon content is estimated by difference). 